\title{
MANFAAT NUTRISI BAGI PERFORMA BURUNG KICAUAN
}

(Benefits of Nutrition For Pet Birds Performance)

\author{
Daryatmo, J. ${ }^{1}$ dan B. P. Widiarso ${ }^{2}$ \\ ${ }^{1,2)}$ Sekolah Tinggi Penyuluhan Pertanian Magelang \\ Jl. Magelang-Kopeng Km 7 Purwosari Tegalrejo Magelang 56192 \\ E-mail : jkodr@yahoo.com; budipw2000@gmail.com
}

Diterima : 28 Desember 2015 Disetujui: 25 Juni 2016

\begin{abstract}
Many of the problems such as poor health, poor fertility and hatchability, and decreased life span can be related to poor nutrition. Improper nutrition can leave the bird susceptible to many diseases and result in overall poor performance and lack of vitality. The term "improper nutrition" does not always mean undernutrition. It can also refer to overnutrition. Providing too much food (often referred to as treats) too often and providing too much of a good thing (i.e., too little variety) is often the cause of the problem. There are more than 8000 species of birds alive today. There will probably never be an ideal diet for all bird species. However, for the average pet bird owner a general knowledge about basic nutritional concepts and feeding can be of benefit when decisions have to be made (Butcher and Miles, 2014). Probiotics, a highly concentrated source of beneficial bacteria, keep your birds intestines healthy and balanced minimizing the effects of harmful bacteria. It's the harmful bacteria that cause diarrhea and other digestive upsets resulting in an inability to absorb nutrients (Burroughs, 1998). All animals have billions of beneficial bacteria in their digestive system as well as harmful bacteria. Birds are no exception. Helpful bacteria aid actually aid the digestion process and help in nutritional absorption. Without beneficial bacteria, our guts would become over-populated with harmful bacteria that can make us sick. It is thought the beneficial bacteria in the gut is species specific. It is not suitable to give the bird human grade probiotics, or those developed for use in dogs (Burroughs, 1998). It can be concluded that feeding a balanced, varied diet will play a major role in helping your pet bird live a long and healthy life.
\end{abstract}

Keywords: Nutrition, Performance, Pet birds

\begin{abstract}
ABSTRAK
Banyak masalah yang bisa terjadi pada burung berkicau, seperti kesehatan yang buruk, rendahnya kesuburan dan daya tetas dan penurunan rentang hidup dapat berhubungan dengan gizi buruk. Nutrisi yang tidak tepat dapat menyebabkan burung rentan terhadap banyak penyakit dan mengakibatkan performa yang buruk secara keseluruhan dan kurangnya vitalitas. Istilah "gizi yang tidak tepat" tidak selalu berarti kekurangan gizi, dapat juga berarti kelebihan gizi. Menyediakan terlalu banyak makanan dengan frekuensi terlalu sering dan memberikan terlalu banyak hal yang baik serta kurang bervariasi seringkali menjadi penyebab masalah Ada lebih dari 8000 jenis burung, mungkin tidak akan pernah ada diet yang ideal untuk semua jenis burung. Namun, untuk rata-rata pemilik burung peliharaan pengetahuan umum tentang konsep-konsep nutrisi dasar dan makanan dapat bermanfaat ketika keputusan harus dibuat (Butcher and Miles, 2014). Probiotik, sumber bakteri menguntungkan yang sangat terkonsentrasi, menjaga usus
\end{abstract}


burung tetap sehat dan seimbang serta meminimalkan efek dari bakteri berbahaya. Bakteri berbahaya yang menyebabkan diare dan gangguan pencernaan lainnya yang mengakibatkan ketidakmampuan untuk menyerap nutrisi (Burroughs, 1998). Semua hewan memiliki miliaran bakteri menguntungkan dalam sistem pencernaan mereka serta bakteri berbahaya. Burung tidak terkecuali. Bakteri bermanfaat benar-benar membantu proses pencernaan dan membantu dalam penyerapan nutrisi. Tanpa bakteri menguntungkan, usus akan menjadi lebih banyak diisi dengan bakteri berbahaya yang dapat membuat sakit. Diperkirakan bakteri menguntungkan dalam usus adalah spesies tertentu. Tidak cocok memberikan burung probiotik kelas manusia, atau yang dikembangkan untuk digunakan pada anjing (Burroughs, 1998). Dapat disimpulkan bahwa pakan seimbang, diet bervariasi akan memainkan peran utama dalam membantu burung peliharaan hidup panjang dan sehat.

Kata kunci: Nutrisi, Performa, Burung kicauan

\section{PENDAHULUAN}

Burung dipelihara pada dasarnya untuk memberikan kepuasan bagi pemiliknya karena dapat memberikan suasana alami berupa penampilan bentuk, warna dan kicauannya yang indah. Selain itu banyak juga penggemar burung memelihara burung untuk tujuan kontes baik berupa kontes kicauan ataupun warna dan kesempurnaan bentuk tubuh. Kegemaran terhadap burung telah membuat daya tarik sendiri sehingga muncul kelompok-kelompok pecinta burung. Ada cukup banyak jenis burung yang disukai (Zaka, 2014) antara lain: 1. Kacer; 2. Kenari; 3. Pleci/Cici (Kaca Mata); 4. Branjangan; 5. Cucak Rawa/Cucak Rowo; 6. Ciblek; 7. Jalak Suren; 8. Cucak Hijau (Cucak Ijo); 9. Paca Warna; 10. Tledekan; 11. Anis Kembang; 12. Anis Merah; 13. Murai Batu; 14. Pentet/Cendet/Plentet; 15. Burung Gelatik; 16. Kolibri (Colibri); 17. Cipoh/Cipo/Cipow/Cito/Sito/Sirtu; 18. Love Bird/Labed; 19. Trucukan/Trocok; 20. Cucak Jenggot; 21. Burung Platuk.

\section{Pakan burung kicauan}

Hal yang perlu diperhatikan adalah kecocokan antara pakan dengan jenis burung Hal utama yang perlu diperhatikan dalam masalah pakan adalah bahwa pakan tersebut memenuhi unsur-unsur karbohidrat, lemak, protein, vitamin, dan mineral. Jika semua unsur terpenuhi dan jumlahnya mencukupi maka kesehatan burung peliharaan itu dapat tetap terjaga. Selanjutnya dampak yang diharapkan yaitu burung mempunyai kicau yang merdu, bulu yang indah, dan perilaku yang lincah. Unsur-unsur penting dalam pakan burung:

1. Karbohidrat. Karbohidrat berfungsi sebagai sumber energi, pembakar lemak, memperkecil oksidasi protein menjadi energi, dan memelihara fungsi normal alat-alat pencernaan. Kadar karbohidrat dalam tubuh burung adalah $2 \%$, sementara pakan burung yang baik adalah yang mengandung 70\% karbohidrat, yaitu terdapat pada pepaya, kacang tanah, kacang hijau, kacang kedelai, dan pisang.

2. Protein. Kekurangan protein menyebabkan burung menjadi kurus, bulu rusak, kerdil, kanibalisme, murung, enggan berkicau, serta sering kali berperilaku mencabuti bulunya sendiri. Burung berkicau membutuhkan $35 \%$ protein dari berat badannya. Protein ini dapat diperoleh 
antara lain dari ikan, susu, cacing, kacang tanah, kacang panjang, kacang hijau, kacang kedelai.

3. Lemak. Lemak merupakan sumber energi, saluran air metabolik, insulator (pengatur suhu tubuh), sebagai bantalan atau pelindung bagian tubuh, serta sebagai pembawa vitamin A, D, E, dan K. Apabila burung terlalu banyak mengonsumsi lemak maka burung ini berpeluang untuk mencret atau gemuk. Padahal burung yang gemuk cenderung malas berkicau dan berbiak.

4. Vitamin dan asam amino. Vitamin berfungsi untuk membantu pembentukan dan pemeliharaan selsel jaringan epitel, memperlancar metabolisme, membentuk jaringan pengikat, membantu pembentukan tulang, dan membantu proses pembentukan darah. Vitamin-vitamin utama dan asam amino yang dibutuhkan burung antara lain adalah A, D3, E, B1, B2, B3 (Nicotimanide) B6, B12, C dan K3; Zat esensial seperti D-L Methionine, I-Lisin $\mathrm{HCl}$, Folic Acid (sesungguhnya adalah salah satu bentuk dari Vitamin B) dan Ca-D Pantothenate.

5. Mineral. Mineral merupakan pembentuk in-organik yang ada di seluruh jagad raya. Tubuh makhluk hidup dibentuk dari mineral. Mineral juga membantu proses kimia dan elektrik yang terjadi di dalam tubuh makhluk hidup. Proses -proses kimia dan elektrik hanya akan berfungsi dengan benar apabila keseimbangan mineral yang sesuai diberikan pada sistem. Misalnya zat besi untuk darah, belerang untuk otot, kalsium untuk tulang, dan banyak lainnya yang secara umum memberikan kelancaran fungsional tubuh makhluk hidup. Mineral dibutuhkan untuk pembentukan darah dan tulang, keseimbangan cairan tubuh, fungsi syaraf yang sehat, fungsi sistem pembuluh darah jantung dan lain-lain. Seperti vitamin, mineral berfungsi sebagai ko-enzim, memungkinkan tubuh melakukan fungsinya seperti memproduksi tenaga, pertumbuhan dan penyembuhan. Meskipun vitamin begitu penting, vitamin tidak dapat melakukan apa-apa untuk makhluk hidup tanpa mineral. Tubuh makhluk hidup dapat menghasilkan beberapa vitamin, tapi tidak dapat menghasilkan satu pun mineral.

Mineral yang diperlukan burung antara lain adalah Calcium, Phosphor, Iron, Manganase, Iodium, Cuprum, Zinccum, Magnesium, Sodium Chlorin dan Kalium. Jika burung kecukupan mineral, maka burung akan memiliki bulu kuat, mulus, berkilau sehabis molting atau ngurak alias mabung; tidak terkena rachitis (tulangtulang lembek, bengkok dan abnormal); bebas paralysa (lumpuh); bebas perosis (tumit bengkak); anak burung menetas sehat; burung tidak mengalami urat keting (tendo); tidak terlepas sendinya, tidak tercerai (luxatio); paruh tidak meleset, tidak kekurangan darah sehingga pucat dan lemah; burung di penangkaran bisa segera bertelur, telur berisi, produktivitas tinggi, daya tetas tinggi serta kematian embrio rendah.

\section{Jumlah pakan yang tepat}

Jumlah pakan yang diberikan untuk burung harus mencukupi kebutuhan, tetapi tidak berlebih. Jumlah yang cukup ini biasanya dapat diperkirakan berdasarkan 
pengamatan dan pengalaman sehari-hari pada burung peliharaan. Pakan diberikan dua kali sehari, pagi dan siang hari. Pada pagi hari biasanya jumlahnya lebih banyak daripada pakan yang diberikan pada siang hari karena pada pagi hari burung lebih aktif makan. Setiap hari pakan harus diganti dengan yang baru, terutama bila pakan berupa buah-buahan karena buah yang sudah basi dapat menyebabkan burung menjadi sakit. Jumlah pakan yang dimakan seekor burung dalam sehari sangat tergantung pada faktor-faktor berikut:

1. Berat badan burung. Berat badan burung berkisar dari burung kolibri yang berbobot sekitar $10 \mathrm{~g}$ sampai burung unta yang berbobot sekitar $100 \mathrm{~kg}$. Burung darat dengan bobot 100-1.000 g dapat makan sebanyak 59\% dari berat tubuhnya dalam sehari, sedangkan burung berkicau yang berbobot 1-90 g dapat makan sebanyak 10-30\% dari bobot badannya per hari.

2. Jenis pakan. Jenis pakan juga mempengaruhi jumlah pakan yang dimakan burung. Burung pemakan biji, misalnya, dapat makan per hari scbanyak $10 \%$ dari berat badannya. Sementara burung pemakan serangga mampu makan sebanyak $40 \%$ dari berat badannya. Hal ini terjadi karena serangga lebih banyak mengandung air daripada biji-bijian.

3. Umur burung. Umur burung juga berpengaruh terhadap jumlah pakan yang dimakan seekor burung dalam sehari. Burung dewasa akan memakan pakan sekitar 10-40\% dari berat badannya, sedangkan anak burung dapat makan sebanyak berat tubuhnya sendiri dalam sehari.

4. Tingkat metabolisme tubuh. Burung yang berukuran kecil, seperti burung penghisap madu dan burung kacamata, mempunyai nilai metabolisme tubuh yang lebih besar daripada burung yang berukuran besar seperti poksai, jalak, atau kasuari. Dengan demikian, burungburung kecil ini juga memerlukan jumlah pakan yang lebih besar daripada burung-burung besar. Jumlah pakan yang diberikan juga berkaitan dengan luas sangkar tempat hidup burung. Jika burung menempati sangkar yang kecil maka pakan yang diberikan lebih sedikit dibandingkan dengan pakan yang diberikan kepada burung yang menempati sangkar yang lebih besar. Di dalam sangkar yang kecil energi yang dikeluarkan burung relatif kecil jika dibandingkan dengan burung yang menempati sangkar besar.

Di samping faktor-faktor yang telah disebutkan, burung juga mempunyai selera terhadap suatu jenis pakan. Gejala ini disebut sebagai palatabilitas. Gejala palatabilitas ini tergantung kepada beberapa faktor yaitu satwa yang bersangkutan, pakan kesukaannya, kondisi pakan yang diberikan (dalam keadaan segar atau sudah basi), serta kesempatan memilih pakan yang lain. Penelitian menunjukkan bahwa pakan yang paling digemari oleh burung pemakan serangga adalah kroto basah, kemudian ulat hongkong, disusul oleh pepaya, dan terakhir atau pakan yang paling tidak disukai burung adalah kroto halus.

\section{Berbagai Jenis Pakan Burung}

Pakan burung dapat berupa pakan hewani dan pakan nabati.

1. Hewani. Pakan hewani untuk burung antara lain kroto, serangga dan 
berbagai jenis ulat, cacing, ikan, daging, telur ayam/unggas lain, serta susu.

a. Kroto. Kroto merupakan larva semut ataupun semut rangrang (Oecophylla smaragdina) yang banyak digemari oleh burungburung pemakan serangga, seperti jalak, kutilang, beo, dan poksai. Menurut jenisnya, kroto dibedakan menjadi kroto basah, kroto halus, kroto kasar, dan kroto kacang.

1) Kroto basah merupakan kroto yang paling banyak digemari oleh burung dan juga sebagai umpan pancing. Kroto jenis ini merupa-kan telur dan larva semut rangrang yang masih baru yang mem-punyai kandungan air tertinggi $(78,72 \%)$ sehingga mudah sekali busuk. Jika tanpa pengawetan, umur kroto basah hanya dapat bertahan sehari. Kroto basah sebaiknya disimpan di dalam lemari pendingin dan dibungkus dulu dengan kertas agar air terserap kerta. Dalam kondisi ini kroto basah dapat bertahan hingga tiga hari. Di antara berbagai jenis kroto, kroto basah mempunyai kandungan gizi yang terbaik, terutama protein, yaitu $47,80 \%$.

2) Kroto halus berupa semutsemut pekerja kecil dan besar. Tanpa pengawetan, jenis kroto ini dapat tahan selama seminggu. Di antara berbagai jenis kroto, kroto halus merupakan jenis yang paling tidak disukai burung.

3) Kroto kasar berupa induk semut ratu dan semut jantan. Jenis kroto ini juga dapat tahan seminggu.

4) Kroto kacang berupa campuran ketiga jenis kroto, yaitu kroto basah, kroto halus, dan kroto kasar, ditambah dengan jenis pakan lain, seperti kacang, jagung, padi, dedak, voer, dan beras ketan. Kroto ini dapat tahan dalam seminggu, tanpa pengawetan. Di antara jenis kroto yang lain, kroto kacang mempunyai kandungan lemak yang tertinggi $(17,07 \%)$.

b. Serangga dan ulat. Banyak burung berkicau merupakan pemakan serangga, selain buahbuahan sebagai pakan tambahannya. Serangga yang banyak dijual di pasaran adalah jangkerik (Gryllus mitratus), sedangkan ulatnya berupa ulat hongkong, ulat bambu dan ulat kandang.

1) Ulat hongkong (Tenebrio mollitor) termasuk salah satu jenis pakan yang digemari burung. Berbagai jenis burung sangat menggemarinya. Selain semua jenis burung pemakan serangga, ulat ini juga disukai oleh elang, kuntul, rajaudang, dan nuri. Berbeda dengan kroto, jenis pakan ini sudah dapat dibudidayakan sehingga setiap saat tersedia di pasaran. 
2) Ulat bambu (Erionota thrax)

biasanya dijual dalam

kemasan bumbung bambu.

Berbeda dengan ulat

hongkong, ulat ini

mempunyai kulit yang lebih

tipis dan lunak sehingga

kandungan kitin di dalamnya

juga lebih sedikit. Dengan

kondisi tubuhnya seperti ini maka ulat ini mempunyai nilai gizi yang lebih baik untuk burung, terutama untuk anak-anak burung, yang sistem pencernaannya tergolong masih peka.

c. Ikan. Ikan termasuk salah satu jenis pakan burung, terutama untuk jenis burung pemakan ikan (Piscivora) seperti kuntul, bangau, blekok, rajaudang, dan elang laut. Jenis ikan yang biasa diberikan adalah ikan mujahir dalam kondisi hidup.

d. Daging. Pakan berupa daging biasanya dikonsumsi oleh burung-burung pemangsa (predator) dan pemakan daging (karnivora). Daging ini dapat berasal dari berbagai hewan seperti sapi, kelinci, ayam, itik manila, dan tikus putih. Sementara pemangsanya adalah burung hantu, elang, rangkong, kasuari, dan gagak. Daging ini dapat disajikan dalam bentuk potongan kecil atau dalam bentuk hidup, seperti anak ayam (DOC) dan tikus putih (mencit) untuk burung hantu dan elang.

e. Susu. Jenis pakan ini umumnya diberikan kepada anak-anak burung dari keluarga merpati (Columbidae) dan paruh bengkok
(Psittacidae) seperti nuri dan kakatua. Meskipun sudah dewasa, kadangkala burungburung ini masih menyukai susu. Semua jenis susu dapat diberikan kepada burung, tetapi yang terbaik adalah susu yang berkadar lemak rendah.

f. Telur ayam/unggas lain. Telur ayam atau unggas lain yang direbus juga bisa diberikan untuk pakan burung, terutama burungburung anakan.

g. Cacing.

2. Nabati. Pakan nabati dapat berupa sayuran, buah-buahan, dan biji-bijian.

a. Sayuran. Sayuran biasa diberikan kepada burung, terutama untuk suku ayam hias (Phasianidae) seperti ayam, merak, kuau, dan puyuh. Pakan sayuran ini disukai pula oleh bebek, kakatua, dan parkit dan kenari. Jenis sayuran yang biasa diberikan adalah kecambah (taoge), kangkung, dan wortel untuk kakatua.

b. Buah-buahan. Hampir semua burung menyukai buah-buahan sebagai pakan utamanya atau hanya sebagai pakan tambahan. Di antara buah-buahan yang tersedia di pasar, buah yang banyak disukai burung adalah pepaya dan pisang kepok yang sudah matang. Buah untuk pakan sebaiknya yang matang pohon, jangan yang matang karena dikarbit. Selain itu, ada jenis buah lain yang juga disukai oleh burung, seperti buni, kersen (ceri), salam, beringin, dan palem.

c. Biji-bijian. Biji-bijian yang dapat diberikan kepada burung antara 
lain biji-bijian halus maupun bijibijian kasar.

1) Biji-bijian halus: Biji-bijian jenis ini disukai oleh burungburung perkutut, kakatua kelabu australia, dan betet afrika (lovebird). Jenis pakan ini meliputi biji-bijian yang berukuran kecil dan halus, yaitu milet (Panicum sp. dan Penisetum glaucum), jewawut (Panicum italia), kenari biji (canary seed, Phallaris canariensis), beras ketan hitam, pellet (voer) 511.

2) Biji-bijian kasar Biji-bijian ini disukai oleh burungburung dari keluarga (suku) ayam hias (Phasianidae) seperti ayam hutan (merah dan hijau), kuau, merak, puter, dan tekukur. Bijibijian kasar ini meliputi bijibijian berukuran agak besar dan kasar, seperti jagung kering, gabah, beras merah, kacang hijau, pellet (voer) 521.

\section{Probiotik untuk burung kicauan}

Probiotik adalah mikroorganisme hidup non patogenik yang dapat dikonsumsi dalam jumlah tertentu akan memberikan efek yang menguntungkan bagi inangnya. Probiotik menekan pertumbuhan bakteri patogen pada manusia seperti Salmonella sp, Helyobacter plyori dan Clostridium prefringes. Contohnya pada andungan probiotik dalam susu/makanan bayi bertujuan menjaga daya tahan tubuh si bayi supaya tidak mudah sakit. Bakteri Probiotik yang sering ditambahkan dalam susu formula bayi, antara lain: Bifidiobacterium sp dan Lactobactillus sp.

Tidak semua spesies mikroba dapat dipakai sebagai probiotik, melainkan harus mempunyai syarat-syarat sebagai berikut: merupakan bakteri yang berasal dari manusia (secara alami terdapat dalam tubuh manusia), tidak bersifat patogen, tahan terhadap enzim pencernaan, asam lambung dan empedu, mampu menempel pada dinding saluran cerna dan bertahan dalam populasi yg banyak, mampu menghasilkan zat antimikroba dan meningkatkan sistem imun tubuh, tahan terhadap proses pembuatan sediaan, stabil secara genetik.

Probiotik menekan pertumbuhan bakteri patogen melalui berbagai macam mekanisme, antara lain: memproduksi senyawa-senyawa yang menghambat pertumbuhan bakteri patogen. senyawa ini berupa asam organik, hidrogen peroksida, bakteriosin, reurin, secara kompetitif dengan bakteri patogen pada reseptor yang sama dalam usus manusia, merusak reseptor toksin dan menginaktifkan toksin yang dihasilkan oleh bakteri patogen, meningkatkan sistem imun melalui peningkatan limfosit B dan imunoglobulin A, berebut nutrisi atau makanan yang sama dengan bakteri patogen.

Prebiotik adalah senyawa golongan karbohidrat rantai pendek (antara 10-15 atom C) yang tidak dicerna seperti inulin, laktulosa dan laktoferrin, mannooligosakarida (MOS), frukto-oligosakarida (FOS) dan gluko-oligosakarida (GOS). Dalam saluran cerna, prebiotik tidak dicerna karena tahan terhadap enzim pencernaan tetapi difermentasikan menjadi asam laktat yang merupakan nutrisi yang diperlukan untuk perkembangan bakteri probiotik dan menghambat pertumbuhan bakteri patogen. Simbiotik antara probiotik dan prebiotik menghasilkan efek yang baik 
bagi kesehatan pencernaan. Kombinasi keduanya penting terdapat dalam susu/makanan (Farmakonina, 2011).

Makanan probiotik mengacu pada makanan yang mengandung bakteri hidup. Bakteri Lactobacillus dan Bifidobacteria dan organisme hidup yang paling umum digunakan. Probiotik umumnya ditemukan dan ditambahkan dalam yogurt dan banyak merek Lactobacillus yoghurt menghasilkan khusus diformulasikan yoghurt prebiotik (Anonimus, 2015).

Minuman probiotik menjadi daya tarik sendiri bagi sebagian kalangan orang yang mengerti akan arti pentingnya zat gizi dan fungsi bagi tubuh. Berbagai penelitian telah dilakukan tentang minuman probiotik. Minuman probiotik berfungsi sebagai penyerap zat-zat yang berbahaya dan memakan mikroorganisme patogen yang dapat menyebabkan penyakit pada tubuh manusia terutama pada sistem pencernaan manusia. Minuman probiotik juga kaya akan protein, mengingat mikroorganisme yang digunakan dalam minuman ini tergolong dalam bakteri penghasil protein sel tunggal. Ada sekian banyak jenis bakteri yang dapat dimanfaatkan sebagai minuman probiotik. Lactobacillus acidophilus, adalah salah satu contoh bakteri yang dapat dimanfaatkan sebagai minuman probiotik. Bakteri ini bersifat gram positif, menggunakan sumber laktosa dan bahan lain sebagai sumber nutrisinya.

Minuman probiotik merupakan salah satu jenis produk yang diolah tanpa melalui proses pemanasan. Minuman probiotik merupakan produk minuman fermentasi berbasis susu atau sari buah yang tidak mengandung alkohol dan baik bagi kesehatan pencernaan. Jenis kultur mikrobia yang umumnya digunakan berasal dari kelompok bakteri asam laktat (Rahayu, 2000). Lactobacillus plantarum sering digunakan secara luas dalam industri fermentasi sayur dan buah karena sebagian besar strain bakteri ini bersifat probiotik (Zubaidah et al., 2008). Saat ini, masyarakat tidak lagi memandang bahan pangan hanya dari kandungan gizi utamanya, namun juga zat nongizi yang dapat memberikan manfaat bagi kesehatan tubuh. Menurut International Food Information Council (2011), pangan fungsional adalah pangan yang dapat memberikan efek kesehatan di luar zat gizi dasar yang terkandung di dalam bahan pangan tersebut. Oleh karena itu, penambahan Lactobacillus plantarum pada ekstrak mahkota dan kelopak bunga rosella, diharapkan dapat menghasilkan minuman kesehatan multifungsional, yaitu dapatmenurunkan tekanan darah, mengandung antioksidan, dan baik bagi kesehatan pencernaan.

\section{Sejarah Probiotik}

Firmansyah (2001) menyatakan bahwa probiotik berasal dari bahasa Yunani pro bios yang berarti "untuk kehidupan". Sejarah probiotik dimulai dari awal peradaban manusia; keju dan susu fermentasi amat dikenal oleh bangsa Yunani dan Romawi dan dianjurkan diberikan pada anak dan orang yang baru sembuh dari penyakit. Selanjutnya dikatakan bahwa Probiotik adalah mikroorganisme yang bila dikonsumsi per oral akan memberikan dampak positif bagi kesehatan manusia dan merupakan galur flora usus normal yang dapat diisolasi dari tinja manusia sehat.

Kaitan ilmiah antara probiotik dan manfaatnya bagi kesehatan pertama kali diungkapkan oleh ahli mikrobiologi Rusia bernama Metchnikoff (1907). Ia menyatakan bahwa asam laktat yang 
dihasilkan oleh Lactobacillus dalam yogurt dapat menghambat pertumbuhan beberapa spesies bakteri patogen. Hubungan antara mikroflora usus dan pejamu ternyata sangat spesifik sehingga perubahan keseimbangan mikroorganisme dapat menimbulkan penyakit. Penggunaan antibiotik dapat merusak keseimbangan mikroflora usus sehingga dapat menimbulkan dampak samping yang tidak diinginkan. Dalam 10 tahun terakhir ini, penelitian mengenai probiotik dan prebiotik berkembang sangat pesat. Terdapat bukti bahwa probiotik bermanfaat dalam pencegahan dan pengobatan beberapa penyakit saluran cerna, termasuk diare infeksi, diare karena antibiotik, travellers diarrhea dan intoleransi laktosa. Penggunaan probiotik sejauh ini aman. Penggunaan prebiotik yang dapat merangsang pertumbuhan kuman probiotik dalam saluran cerna mulai banyak mendapat perhatian (Firmansyah, 2001).

Lactobacillus sp. Lactobacillus adalah genus bakteri berbentuk batang, bagian dari kelompok bakteri asam laktat. Sebagian besar bakteri Lactobacillus jinak dan berhubungan dengan banyak manfaat kesehatan. Bakteri ini hidup di usus dan melaksanakan fungsi kesehatan yang penting. Sebagai contoh, mereka memfermentasi serat dan mengubahnya menjadi asam lemak rantai pendek - ini dapat melindungi terhadap kanker. Selain itu, mereka membuat lingkungan usus asam; menghambat pertumbuhan bakteri berbahaya.

Sumber makanan dari Bakteri Lactobacillus. Lactobacillus sp. ditemukan di sebagian besar fermentasi makanan antara lain yoghurt, keju, asinan kubis, acar, bir, anggur, sari dan cokelat. Selain itu mereka yang saat ini ditambahkan ke banyak makanan, membuat mereka 'makanan fungsional'.

Probiotik. Makanan probiotik mengacu pada makanan yang mengandung bakteri hidup. Bakteri lactobacillus dan bifidobacteria dan organisme hidup yang paling umum digunakan. Probiotik umumnya ditemukan dan ditambahkan dalam yogurt dan banyak merek lactobacillus yoghurt menghasilkan khusus diformulasikan yogurt prebiotik.

Jenis. Ada lebih dari 125 spesies di genus Lactobacillus: Lactobacillus acetotolerans, Lactobacillus acidifarinae, Lactobacillus acidipiscis, Lactobacillus acidophilus, Lactobacillus agilis, Lactobacillus algidus, Lactobacillus alimentarius, Lactobacillus amylolyticus, Lactobacillus amylophilus, Lactobacillus amylotrophicus, Lactobacillus amylovorus, Lactobacillus animalis, Lactobacillus antri, Lactobacillus apodemi, Lactobacillus aviarius, Lactobacillus bifermentans, Lactobacillus brevis, Lactobacillus buchneri, Lactobacillus camelliae, Lactobacillus casei, Lactobacillus catenaformis, Lactobacillus ceti, Lactobacillus coleohominis, Lactobacillus collinoides, Lactobacillus composti, Lactobacillus concavus, Lactobacillus coryniformis, Lactobacillus crispatus, Lactobacillus crustorum, Lactobacillus curvatus, Lactobacillus delbrueckii subsp. Delbrueckii, Lactobacillus delbrueckii subsp. Bulgaricus,Lactobacillus delbrueckii subsp. Lactis, Lactobacillus dextrinicus, Lactobacillus diolivorans, Lactobacillus equi, Lactobacillus equigenerosi, Lactobacillus farraginis, Lactobacillus farciminis, Lactobacillus fermentum, Lactobacillus fornicalis, Lactobacillus fructivorans, Lactobacillus frumenti, Lactobacillus fuchuensis, Lactobacillus gallinarum, Lactobacillus gasseri, 
Lactobacillus gastricus, Lactobacillus ghanensis, Lactobacillus graminis, Lactobacillus hammesii, Lactobacillus hamsteri, Lactobacillus harbinensis, Lactobacillus hayakitensis, Lactobacillus helveticus, Lactobacillus hilgardii, Lactobacillus homohiochii, Lactobacillus iners, Lactobacillus ingluviei, Lactobacillus intestinalis, Lactobacillus jensenii, Lactobacillus johnsonii, Lactobacillus kalixensis, Lactobacillus kefiranofaciens, Lactobacillus kefiri, Lactobacillus kimchii, Lactobacillus kitasatonis, Lactobacillus kunkeei, Lactobacillus leichmannii, Lactobacillus lindneri, Lactobacillus malefermentans, Lactobacillus mali, Lactobacillus manihotivorans, Lactobacillus mindensis, Lactobacillus mucosae, Lactobacillus murinus, Lactobacillus nagelii, Lactobacillus namurensis, Lactobacillus nantensis, Lactobacillus oligofermentans, Lactobacillus oris, Lactobacillus panis, Lactobacillus pantheris, Lactobacillus parabrevis, Lactobacillus parabuchneri, Lactobacillus paracollinoides, Lactobacillus parafarraginis, Lactobacillus parakefiri, Lactobacillus paralimentarius, Lactobacillus paraplantarum, Lactobacillus pentosus, Lactobacillus perolens, Lactobacillus plantarum, Lactobacillus pontis, Lactobacillus psittaci, Lactobacillus rennini, Lactobacillus reuteri, Lactobacillus rhamnosus, Lactobacillus rimae, Lactobacillus rogosae, Lactobacillus rossiae, Lactobacillus ruminis, Lactobacillus saerimneri, Lactobacillus sakei, Lactobacillus salivarius, Lactobacillus sanfranciscensis, Lactobacillus satsumensis, Lactobacillus secaliphilus, Lactobacillus sharpeae, Lactobacillus siliginis, Lactobacillus spicheri, Lactobacillus suebicus, Lactobacillus thailandensis, Lactobacillus ultunensis, Lactobacillus vaccinostercus, Lactobacillus vaginalis, Lactobacillus versmoldensis, Lactobacillus vini, Lactobacillus vitulinus, Lactobacillus zeae, Lactobacillus zymae (Anonimus, 2015).

Probiotik menjadi nama umum sebagai penjaga keseimbangan micro ecosystem (atau ekosistem mikro). Dalam sistem pencernaan ia membantu proses pencernaan, berperan positif dalam sistem immun dan menetralkan atau menghilangkan racun. Hal ini tentu saja karena peran baik dari sekumpulan mikroorganisme yang terkandung di dalamnya.

Secara umum terdapat 5 golongan yang pokok yaitu, bakteri fotosintetik, Lactobacillus sp., Streptomycetes sp., Ragi (yeast), dan Actinomycetes. Bakteri Lactobacillus sp merupakan bakteri yang sangat bermanfaat selama pencernaan makanan, meningkatkan efisiensi nutrisi dalam pakan, serta mengurangi bau pada feses yang dihasilkannya. Oleh karenanya, pada peternakan; aplikasinya dapat melalui makanan atau minuman. Jika aplikasinya diterapkan pada makanan burung, maka diharapkan akan terjadi proses fermentasi terhadap pakan; dan diharapkan akan meningkatkan efisiensi pakan tersebut. Jadi akan menjadi cukup beralasan, jika produkproduk probiotik ini sering digunakan sebagai campuran dalam pakan.

\section{KESIMPULAN}

Kalau diperluas, manfaat dari probiotik ini pun akan makin banyak. Karena manfaatnya adalah di sistem pencernaan, maka implikasinya juga kepada peningkatan daya tahan tubuh, produktivitas, efisiensi pakan, kualitas karkas daging, aroma daging, dan kualitas telur, dan konversi pakan. Jadi sebenarnya, 
manfaatnya tidak saja pada kenari, tapi kepada burung lainnya. Karena burung berkicau itu yang bernilai adalah kicauannya, maka konversi pakan, aroma daging, kualitas karkas, dan beberapa parameter lainnya seringkali diabaikan.

\section{DAFTAR PUSTAKA}

Sucipto, A. Belajar perburungan: EM4 sebagai menu tambahan pada kenari.

http://www.adisucipto.com/2014/02 /belajar-perburungan-em4-sebagaimenu-tambahan-pada-kenari/.

Diakses tanggal 12 Desember 2015.

International Food Information Council Foundation. 2011. Functional Foods.

http://www.foodinsight.org/Content/ 3842/Final\%20Functional\%20Food s\%20Backgrou nder.pdf. Diakses tanggal 12 Mei 2013.

Rahayu, K. K. 2000. Fermentasi Pangan. Pusat Antara Universitas Pangan dan Gizi. Universitas Gadjah Mada, Yogyakarta.

Zubaidah, E., Liasari, Y., dan Saparianti, E. 2008. Produksi Eksopolisakarida oleh Lactobacillus plantarum B2 Pada Produk Probiotik Berbasis Buah Murbei. Jurnal Teknologi Pertanian. 9 (1) : 59-68.

Firmansyah, Agus. 2001. Terapi Probiotik dan Prebiotik pada Penyakit Saluran Cerna Anak. Sari Pediatri, Vol. 2, No. 4, Maret 2001: 210 - 214

Anonimus. 2015. Lactobacillus Sp. Information.

http://www.lactobacillussp.com/. Diakses tanggal 19 Pebruari 2015

Farmakonina. 2011. Probiotik Dan Prebiotik, Apa Bedanya? https://farmakonina.wordpress.com/ 2011/02/01/probiotik-dan-prebiotik- apa-bedanya/. Diakses tanggal 19 Pebruari 2015.

Anonimous. 2007. Masa Pengeraman dan Penetasan.

http://www.kicaumania.org/Forums/ showtread.php. Diakses tanggal 21 Februari 2008.

Hamiyanti, A.A., Achmanu, Muharlien, dan A.P. Putra. 2011. Pengaruh Jumlah Telur Terhadap Bobot Telur, Lama Mengeram, Fertilitas Serta Daya Tetas Telur Burung Kenari. http://ternaktropika.ub.ac.id/index.p hp/tropika/article/view/ 118/129. J. Ternak Tropika Vol. 12, No.1: 95101. Diakses tanggal 10 Januari 2015

Olszewski,A. 1996. Canary FAQ. http://www2.upatsix.com/faq/canary .htm\#. Diakses tanggal 11 Desember 2007.

Saputra, Gita Adi. 2013. Mengenal Burung Kenari.

http://www.satwa.net/579/mengenal -burung-kenari.html. Diakses tanggal 19 Desember 2015

Zaka, Muhammad. 2014. 20 Macam Burung Kicau Termahal. http://muhammadzaka17.blogspot.c o.id/2014/01/20-macam-burungkicau-termahal.html. Diakses tanggal 07 September 2015

Butcher, Gary D. and Richard D. Miles. 2014. Understanding Pet Bird Nutrition. https://edis.ifas.ufl.edu/vm067. Diakses tanggal 19 Desember 2015.

Foster and Smith. Bird Nutrition: Feeding Pet Birds, Parrot Diets, and Nutrition Recommendations. Veterinary and Aquatic Services Department. USA. http://www.peteducation.com/article $. \mathrm{cfm} ? \mathrm{c}=15+1835 \&$ aid $=2844$.

Diakses tanggal 19 Desember 2015.

Diane Burroughs. Are Probiotics For Birds $a$ Good Thing?. 
http://blog.birdsupplies.com/are-

probiotics-for-birds-a-good-thing.

Diakses tanggal 19 Desember 2015.

Anonimous. 2007. Masa Pengeraman dan Penetasan.

http://www.kicaumania.org/Forums/ showtread.php. Diakses Tanggal 21

Februari 2008. 